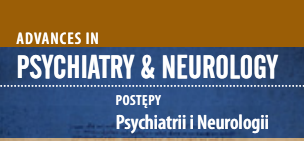

Correspondence to/Adres do korespondencji:

Adam Zabrzygraj

$1^{\text {st }}$ Department of Psychiatry

Mokotow Mental Health Center

Institute of Psychiatry and Neurology

9 Sobieskiego St.

02-957 Warsaw, Poland

phone: +48224582773

fax: +48 22 4582818

e-mail: azabrzygraj@ipin.edu.pl

Submitted/Otrzymano: 02.02.2021

Accepted/Przyjęto do druku: 20.03.2021

\section{Helpline provision during the first wave of the COVID-19 pandemic: experiences of the Mokotow Mental Health Center}

\author{
Linia wsparcia w czasie pierwszej fali \\ pandemii COVID-19: doświadczenia \\ Mokotowskiego Centrum Zdrowia \\ Psychicznego
}

\author{
Adam Zabrzygraj, Piotr Świtaj \\ $1^{\text {st }}$ Department of Psychiatry, Mokotow Mental Health Center, Institute of Psychiatry \\ and Neurology, Warsaw, Poland
}

I Klinika Psychiatryczna, Mokotowskie Centrum Zdrowia Psychicznego, Instyłut Psychiatrii i Neurologii w Warszawie, Polska

\begin{abstract}
Purpose: The purpose of our study was to present the community helpline initiated by the Mokotow Mental Health Center (Mokotowskie Centrum Zdrowia Psychicznego - MCZP) during the first wave of the COVID-19 pandemic, and summarize its performance. Methods: The Mokotow Helpline (Mokotowska Linia Wsparcia - MLW) operated from March to July 2020, providing ad hoc interventions and short-term regular help by psychologists and a social worker.

Results: 599 interventions were delivered to 262 people. Emergency support was given to $70.6 \%$ of callers and regular short-term support was provided to $29.4 \%$. The highest number of people contacted the helpline in the first weeks of its operations, while from May 2020 onwards the frequency of calls systematically decreased. Women requested assistance twice as often as men. The most frequent reasons for contacting the line were the need for advice and support in connection with symptoms of mental illness occurring in a loved one (21.4\%), request for medical services, e.g. appointment with a psychiatrist, prescription renewal or psychotherapy appointment (16.0\%), anxiety (15.6\%), reactive (adjustment) (13.0\%) and depressive disorders (5.7\%) and financial difficulties or loss of a job (5.7\%). The most frequent interventions consisted of psychological support $(73.8 \%)$, information or psychoeducation (16.9\%), and also referring people to institutions that could provide the most appropriate form of help (8.1\%).

Conclusions: The helpline is an easily accessible and practical means of providing assistance to the population in critical situations such as the pandemic. The kind, duration and frequency of this form of help should be varied and adapted to the wide range of problems reported by callers.
\end{abstract}

Key words: helpline, mental health, coronavirus, pandemic, COVID-19.

\title{
Streszczenie
}

Cel: Celem pracy było podsumowanie i opis działania linii wsparcia dla ludności, uruchomionej przez Mokotowskie Centrum Zdrowia Psychicznego (MCZP) w czasie pierwszej fali pandemii COVID-19.

Metody: Mokotowska Linia Wsparcia (MLW) działała od marca do lipca 2020 r. Interwencje doraźne oraz krótkoterminowe interwencje cykliczne były realizowane przez psychologów i pracownika socjalnego.

Wyniki: Podjęto 599 interwencji w stosunku do 262 osób. Wsparcie doraźne otrzymało 70,6\%, a wsparcie cykliczne - 29,4\% osób. Najwięcej osób kontaktowało się z linią wsparcia w pierwszych tygodniach jej funkcjonowania, od maja częstość zgłoszeń systematycznie spadała. Kobiety zgłaszały się dwukrotnie częściej niż mężczyźni. Najczęstszymi powodami kontaktu z MLW były: chęć uzyskania porady i wsparcia w związku z objawami zaburzeń psychicznych występującymi u bliskiej osoby (21,4\%), chęć uzyskania świadczeń medycznych, np. zapisu do psychiatry, otrzymania recept lub zapisu na psychoterapię (16,0\%), zaburzenia lękowe (15,6\%), reaktywne (adaptacyjne) (13,0\%) i depresyjne (5,7\%) oraz trudności finansowe lub utrata pracy (5,7\%). Przeprowadzone interwencje polegały najczęściej na udzieleniu wsparcia psychologicznego $(73,8 \%)$, udzieleniu informacji lub przeprowadzeniu szeroko pojętej psychoedukacji $(16,9 \%)$ oraz na przekierowaniu do instytucji świadczących pomoc najbardziej adekwatną w danej sytuacji $(8,1 \%)$. 
Wnioski: Linia wsparcia jest łatwo dostępnym i praktycznym środkiem udzielania pomocy ludności w kryzysowej sytuacji, takiej jak pandemia. Rodzaj, czas trwania i intensywność tej pomocy powinny być zróżnicowane i dostosowane do szerokiego wachlarza problemów zgłaszanych przez osoby dzwoniące.

Słowa kluczowe: linia wsparcia, zdrowie psychiczne, koronawirus, pandemia, COVID-19.

\section{INTRODUCTION}

At the turn of 2019/2020, the new coronavirus SARS-CoV-2 became a key threat to global public health, quickly leading to a pandemic that not only claimed many hundreds of thousands of lives, but also forced governments to take radical measures to stop the transmission of the dangerous pathogen [1]. These included the isolation of infected populations, quarantine of people who were in contact with the infected individuals, recommendations to maintain social distancing and use personal protective equipment (masks, visors) in public places, prohibition of assembly, closure of schools and universities, promotion of remote work and learning, restrictions on movement, and finally a total lockdown. Although the duration and scope of these restrictions varied across countries [1, $2]$, they dramatically changed the lifestyles of entire societies and contributed to a severe economic crisis. Poland was no exception. The first case of SARS-CoV-2 infection was reported on 4 March 2020, and further to the regulation of the Minister of Health a state of epidemic emergency has been in force in our country since 20 March 2020.

Both the stress people experienced in the face of a new, previously unknown threat, and the social isolation or pandemic-related restrictions on basic civil rights and freedoms, must have had far-reaching psychosocial consequences that will perhaps only become fully apparent in the long term. Previous research on the impact of the COVID-19 pandemic on indicators of mental health and well-being indicates that it has contributed, among other things, to an increased risk of anxiety and depressive symptoms, PTSD, general levels of perceived stress, sleep disturbances $[3,4]$, suicidal thoughts and tendencies [5], feelings of loneliness [6-8], and altered alcohol consumption patterns $[9,10]$. Among the groups at highest risk for mental health deterioration during the pandemic are coronavirus-infected individuals and their families [3], as well as people under quarantine [11], women [4], people under 40-45 years of age [4, 12] (although the elderly are also thought to be particularly vulnerable to the deleterious effects of social isolation or loneliness associated with the pandemic [13]), people of low socioeconomic status and the unemployed [4],

\section{WPROWADZENIE}

Na przełomie 2019 i 2020 r. nowy koronawirus SARS-CoV-2 stał się kluczowym zagrożeniem dla globalnego zdrowia publicznego, szybko doprowadzając do pandemii, która nie tylko pochłonęła wiele setek tysięcy ofiar, lecz także wymusiła podejmowanie przez władze państw radykalnych środków mających na celu powstrzymanie transmisji niebezpiecznego patogenu [1]. Środki te polegały m.in. na izolacji osób zakażonych, kwarantannie osób mających kontakt $\mathrm{z}$ osobami zakażonymi, nakazie utrzymywania dystansu społecznego oraz używania środków ochrony osobistej (maseczek, przyłbic) w miejscach publicznych, zakazie zgromadzeń, zamknięciu szkół i uczelni, promowaniu pracy i nauki zdalnej, ograniczeniach możliwości przemieszczania się, aż po całkowity lockdown. Choć czas trwania i zakres tych restrykcji różniły się w poszczególnych krajach [1,2], diametralnie zmieniły one styl życia całych społeczeństw i przyczyniły się do poważnego kryzysu ekonomicznego. Polska nie była tu wyjątkiem. Pierwszy przypadek zakażenia wirusem SARS-CoV-2 odnotowano 4 marca 2020 r., a od 20 marca 2020 r., zgodnie z rozporządzeniem Ministra Zdrowia, obowiązuje w naszym kraju stan epidemii.

Zarówno stres przeżywany $\mathrm{w}$ obliczu nowego, nieznanego dotąd zagrożenia, jak i izolacja społeczna czy związane z pandemią ograniczenia podstawowych praw i swobód obywatelskich musiały mieć daleko idące konsekwencje psychospołeczne, które być może ujawnią się $\mathrm{w}$ pełni dopiero w dłuższej perspektywie. Dotychczasowe badania nad wpływem pandemii COVID-19 na wskaźniki zdrowia i dobrostanu psychicznego pokazują, że przyczyniła się ona m.in. do zwiększenia ryzyka wystąpienia objawów lękowych i depresyjnych, PTSD, ogólnego poziomu odczuwanego stresu, zaburzeń snu $[3,4]$, myśli i tendencji samobójczych [5], poczucia samotności [6-8], a także do zmiany wzorców spożywania alkoholu $[9,10]$. Wśród grup w największym stopniu narażonych na pogorszenie zdrowia psychicznego w czasie pandemii wymienia się m.in. osoby zakażone koronawirusem i ich rodziny [3], osoby poddane kwarantannie [11], kobiety [4], osoby poniżej 40.-45. roku życia $[4,12]$ (choć osoby w podeszłym wieku również uważa się za szczególnie podatne na szkodliwy wpływ izolacji społecznej czy samotności związanej z pandemią [13]), osoby o niskim statusie społeczno-ekonomicznym i bezrobotne [4], oso- 
Helpline provision during the first wave of the COVID-19 pandemic: experiences of the Mokotow Mental Health Center Linia wsparcia w czasie pierwszej fali pandemii COVID-19: doświadczenia Mokotowskiego Centrum Zdrowia Psychicznego

those with chronic somatic diseases or mental disorders $[3,4]$, and also health care workers $[3,5,14]$.

Since the negative effects of the pandemic are widespread, posing a threat to the mental health of the entire population under the conditions of limited access to social support resources and mental health facilities, it seems necessary to develop and promote methods of psychological support that can be easily and quickly available to people affected by or at risk of mental crisis, in order to prevent its further development and potential escalation. One such well-proven method is the telephone helpline [15].

The aim of this article is to analyze and summarize the operation of the helpline launched by the Warsaw-based Mokotow District Mental Health Center (Mokotowskie Centrum Zdrowia Psychicznego - MCZP) during the first wave of the COVID-19 pandemic. The MCZP is part of the $1^{\text {st }}$ Department of Psychiatry of the Institute of Psychiatry and Neurology (Instytut Psychiatrii i Neurologiii - IPiN), and the Mokotow Helpline (Mokotowska Linia Wsparcia - MLW) was established in March 2020 in response to the needs reported by the callers to the Mental Health Provision Coordination Points (Punkty Zgloszeniowo-Koordynacyjne - PZK) and other institutions operating in the Warsaw-Mokotow area (a Social Welfare Center, the Warsaw-Mokotow District Office). This coincided with previous plans to expand the MCZP's activity, in connection with the implementation of the project "Comprehensive support for people with mental disorders and diseases in Mokotow district", further in this paper referred to as the Project, within the framework of Measure 4.1 Social Innovation in the Ministry of Funds and Regional Policy. Due to the growing incidence of COVID-19 and the sanitary-epidemiological recommendations in force during the epidemic, it proved impossible to launch the Social Support Coordination Center and the Mobile Social Support Team, despite the fact that an adequate number of staff were employed and that their initial training had been completed. In this situation, a decision was made to temporarily change the channels of social support activities, hence the idea of the helpline which was operated from March 26, 2020 to July 31, 2020 Monday to Friday, from 8:00 a.m. to 8:00 p.m. using a local Warsaw telephone number.

Information about the MLW launch was conveyed to the Press Department and Social Assistance and Social Projects Bureau of the city authorities, the Warsaw-Mokotow District Office, Social Welfare Centers operating in Warsaw-Mokotow area, the Provincial Sanitary and Epidemiological Station, Warsaw Police Headquarters, and the Police District Headquarters for the Warsaw-Mokotow, Warsaw-Ursynow and Warsaw-Wilanow Districts, as well as to the churches in the Warsaw-Mokotow area. The information was also broadcast twice on news bulletins of the Polish Televi- by z przewlekłymi chorobami somatycznymi lub z zaburzeniami psychicznymi $[3,4]$ oraz pracowników opieki zdrowotnej $[3,5,14]$.

$\mathrm{Z}$ uwagi na fakt, że negatywne skutki pandemii mogą być powszechne i zagrażać zdrowiu psychicznemu całej populacji, przy równoczesnym ograniczeniu możliwości korzystania z zasobów wsparcia społecznego oraz dostępu do placówek zdrowia psychicznego, niezbędne wydaje się rozwijanie i promowanie takich metod wsparcia psychologicznego, które byłyby łatwo i szybko dostępne dla osób dotkniętych albo tylko zagrożonych kryzysem psychicznym, tak aby zapobiec jego rozwojowi i eskalacji. Jedną z takich sprawdzonych metod jest telefoniczna linia wsparcia [15].

Celem niniejszego artykułu jest podsumowanie i opis działania linii wsparcia dla ludności uruchomionej przez Mokotowskie Centrum Zdrowia Psychicznego (MCZP) w czasie pierwszej fali pandemii COVID-19. Centrum to stanowi część I Kliniki Psychiatrycznej Instytutu Psychiatrii i Neurologii (IPiN) w Warszawie. Mokotowska Linia Wsparcia (MLW) powstała w marcu 2020 r. jako odpowiedź na zapotrzebowanie zgłaszane przez osoby telefonujące do Punktów Zgłoszeniowo-Koordynacyjnych (PZK) MCZP oraz do instytucji działających na terenie Warszawy-Mokotowa (Ośrodek Pomocy Społecznej, Urząd Dzielnicy Warszawa-Mokotów). Zbiegło się to $\mathrm{w}$ czasie z planami rozszerzenia aktywności MCZP w związku z realizacją projektu „Kompleksowe wsparcie osób z zaburzeniami i chorobami psychicznymi w dzielnicy Mokotów" (dalej: Projekt) w ramach Działania 4.1 Innowacje społeczne w Ministerstwie Funduszy i Polityki Regionalnej. Ze względu na rosnące wskaźniki zachorowań na COVID-19 oraz obowiązujące $\mathrm{w}$ czasie epidemii zalecenia sanitarno-epidemiologiczne niemożliwe okazało się uruchomienie Centrum Koordynacji Wsparcia Społecznego i Mobilnego Zespołu Wsparcia Społecznego, mimo zatrudnienia odpowiedniej liczby personelu oraz przeprowadzenia wstępnego przeszkolenia. $\mathrm{W}$ tej sytuacji podjęto decyzję o tymczasowej zmianie obszaru działań wsparcia społecznego i powołano do życia MLW. Linia wsparcia działała od 26 marca 2020 r. do 31 lipca 2020 r. w dni powszednie w godzinach $8.00-20.00$ pod warszawskim numerem telefonu.

Informacja o uruchomieniu MLW została przekazana do Wydziału Prasowego oraz Biura Pomocy i Projektów Społecznych m.st. Warszawy, Urzędu Dzielnicy Warszawa-Mokotów, ośrodków pomocy społecznej działających na terenie Warszawy-Mokotowa, Wojewódzkiej Stacji Sanitarno-Epidemiologicznej, Komendy Stołecznej Policji, Komendy Rejonowej Policji dla dzielnic Warszawa-Mokotów, Warszawa-Ursynów i Warszawa-Wilanów oraz do kościołów na terenie Warszawy-Mokotowa. Stosowna informacja dwukrotnie była też wyświetlana w programach informacyjnych Telewizji Polskiej TVP Info. Ponadto materiały promocyjne zamieszczono na stronie WWW 
sion TVP Info, some promotional materials were posted on the website and the Facebook profile of the MCZP and on the websites of the IPiN, Warsaw-Mokotow District Office, Warsaw Police Headquarters and Regional Police Headquarters.

\section{METHODS}

\section{Operational principles}

The operational principles for the helpline were developed by the team responsible for the implementation of the Project, while the internal procedures were developed in smaller working teams under the supervision of task coordinators, with the participation of two experienced psychologists.

An ICT solution was used in the form of a digital telephone exchange, with an option to redirect calls to two types of workers - psychologists or a social worker. The caller could choose whether to connect to a psychologist for support or to obtain information on welfare issues. New calls were randomly assigned to the staff on duty. In addition to the ad hoc support provided by most similar projects, the helpline also provided short-term support for individuals in a mental health crisis and sustained support for previously registered Project participants. Short-term support was provided by psychologists in the form of telephone calls or, in a few cases, through video calls. Psychologists with the callers' consent, called back all persons that required support at appointed time, as direct-line numbers to staff were not given out to the public. The duration of support was not pre-determined and was tailored to individual needs.

\section{Analysis of the interventions}

MLW staff completed 792 intervention cards. The caller's phone number was used as an ID for the person calling in. The following data were extracted from the intervention cards: gender and age of the caller, date and time of the intervention, as well as the reason for the call and the type of support provided. The reasons for calling and types of interventions provided by the MLW attendants were then categorized by an experienced psychiatrist (the first author of this paper). One-off interventions may have included different kinds of support, such as psychological help and psychoeducation or providing information on access to the appropriate health services. The main type of support provided during a single interview was coded. The intervention cards containing only information about the call being postponed or a missed call were discarded. Also, multiple contacts made by the same employee on the same day would be treated as one intervention. As a result, the number of interventions was reduced to 701 (for 278 unique phone numbers). In i profilu facebookowym MCZP oraz na stronach internetowych IPiN, Urzędu Dzielnicy Warszawa-Mokotów, Komendy Stołecznej Policji oraz Komendy Rejonowej Policji.

\section{METODY}

\section{Zasady funkcjonowania linii wsparcia}

Założenia dotyczące funkcjonowania linii wsparcia opracował zespół odpowiedzialny za realizację Projektu. Wewnętrzne procedury postępowania stworzono $\mathrm{w}$ mniejszych zespołach roboczych pod nadzorem koordynatorów poszczególnych zadań, z udziałem dwójki doświadczonych psychologów.

Skorzystano z rozwiązania teleinformatycznego w postaci wirtualnej centrali telefonicznej z możliwością przekierowania połączeń do dwóch rodzajów pracowników - psychologów lub pracownika socjalnego. Osoba telefonująca mogła wybrać, czy chce się połączyć z psychologiem w celu uzyskania wsparcia, czy też uzyskać informacje dotyczące spraw socjalnych. Centrala telefoniczna losowo przydzielała nowe połączenia do dyżurujących pracowników. Oprócz doraźnego wsparcia charakteryzującego funkcjonowanie większości podobnych przedsięwzięć, MLW udzielała również wsparcia krótkoterminowego osobom w szeroko rozumianym kryzysie psychicznym oraz wsparcia podtrzymującego wcześniej zarejestrowanym uczestnikom Projektu. Wsparcie krótkoterminowe było realizowane przez psychologów w postaci rozmów telefonicznych lub - w nielicznych przypadkach - poprzez połączenia audiowizualne. Psycholodzy, po uprzednim uzyskaniu stosownej zgody, oddzwaniali do osób wymagających wsparcia pod ustalony numer telefonu w umówionym czasie, gdyż nie udostępniano telefonów bezpośrednich do poszczególnych pracowników. Czas trwania wsparcia nie był z góry ustalony, dostosowywano go do potrzeb zgłaszających się osób.

\section{Analiza przeprowadzonych interwencji}

Pracownicy obsługujący MLW wypełnili 792 karty interwencji. Numer telefonu był unikatowym ID dla zgłaszającej się osoby. Z kart interwencji ekstrahowano następujące dane: płeć i wiek osoby telefonującej, datę i godzinę interwencji, a także powód zgłoszenia oraz rodzaj uzyskanego wsparcia. Odnotowane przez osoby obsługujące MLW powody zgłoszenia się oraz rodzaje interwencji były następnie kategoryzowane przez doświadczonego lekarza psychiatrę (pierwszego autora artykułu). Pojedyncze interwencje mogły obejmować różne rodzaje wsparcia (np. wsparcie psychologiczne i psychoedukację lub udzielenie niezbędnych informacji, jak uzyskać świadczenie zdrowotne) - kodowano wtedy główny rodzaj wsparcia udzielonego w czasie jednej rozmowy. Z analizy zostały odrzucone karty interwencji zawierające jedynie informacje o przełożeniu terminu lub o braku połączenia o wcześniej ustalonej porze. Przyjęto również zasadę, że kilkukrotny kontakt realizowany przez tego samego pracownika w tym samym 
Helpline provision during the first wave of the COVID-19 pandemic: experiences of the Mokotow Mental Health Center Linia wsparcia w czasie pierwszej fali pandemii COVID-19: doświadczenia Mokotowskiego Centrum Zdrowia Psychicznego

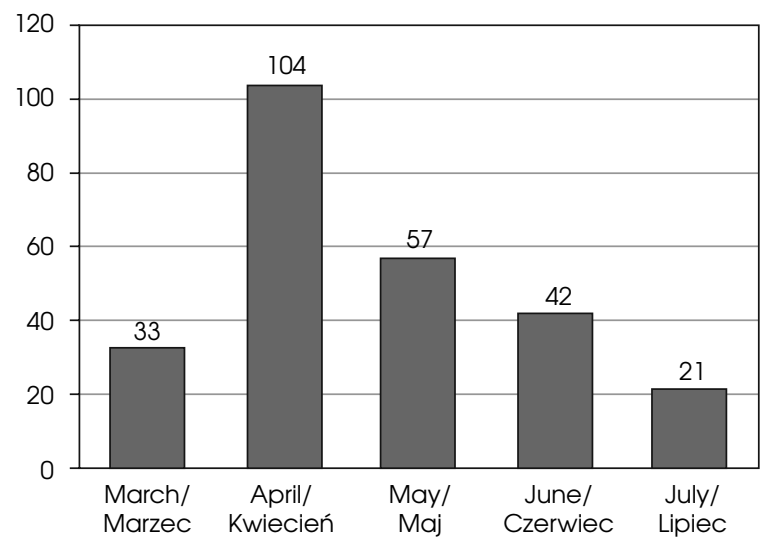

Note: In March 2020, the MLW operated for only several days (beginning on the $26^{\text {th }}$ of March)./

Uwaga: W marcu MLW funkcjonowała tylko przez kilka dni (od 26 marca).

Figure I. Number of new submissions to the MLW in consecutive months $(N=262)$

Rycina I. Liczba nowych zgłoszeń w MLW w kolejnych miesiącach $(N=262)$

the next step, interventions related to maintaining contact with Project participants were filtered out (102 interventions for 20 people; interventions provided to 4 people before they formally joined the Project were nevertheless included in the analysis). Finally, 599 interventions were included in the analysis, involving 262 individuals. These were analyzed both collectively and in a division into ad hoc and cyclical support.

\section{Methods of statistical analysis}

Basic descriptive statistics such as numbers, percentages, arithmetic means, minimum and maximum values were used to characterize the variables.

\section{RESULTS}

The number of new submissions per month averaged $51.4^{1}$, ranging from 21 in July to 104 in April (data for each month are shown in Figure I).

In contrast, the average weekly number of new submissions was 13.5 (min. 3 in the $13^{\text {th }}$ and $16^{\text {th }}$ weeks of the MLW operation [15-19 June 2020 and 06-10 July 2020 ], with a max. of 36 in the $2^{\text {nd }}$ week of the operation [30 March - 03 April 2020]). There was little difference in the average frequency of calls by day of the week (2.7 on Wednesdays; 2.8 on Thursdays and Fridays; 3.0 on Mondays and Tuesdays). Nearly two-thirds of interventions (62\%) occurred between 11:00 a.m. and 4:00 p.m.

Of the total group of individuals contacting the MLW $(N=262)$, ad hoc support was provided to 185 individuals $(70.6 \%)$ and cyclical support was given to 77 (29.4\%).

${ }^{1}$ Taking into consideration only the full months of MLW's operations (April-July), the average number of new calls was 56. dniu będzie traktowany jako jedna interwencja. W efekcie zredukowano liczbę interwencji do 701 (dla 278 unikatowych numerów telefonów). W kolejnym kroku odfiltrowano interwencje dotyczące podtrzymywania kontaktu z uczestnikami Projektu (102 interwencje dla 20 osób; interwencje udzielone 4 osobom przed ich formalnym przystąpieniem do Projektu zostały jednak uwzględnione w analizie). Ostatecznie do analizy włączono 599 interwencji, które objęły 262 osoby. Przeprowadzone interwencje analizowano zarówno łącznie, jak i z uwzględnieniem podziału na wsparcie doraźne i cykliczne.

\section{Metody analizy statystycznej}

Do charakterystyki zmiennych wykorzystano podstawowe statystyki opisowe, takie jak: liczebność, odsetek, średnia arytmetyczna, wartość minimalna i maksymalna.

\section{WYNIKI}

Liczba nowych zgłoszeń miesięcznie wynosiła średnio 51,4 ${ }^{1}$, wahając się od $21 \mathrm{w}$ lipcu do $104 \mathrm{w}$ kwietniu (dane dla poszczególnych miesięcy przedstawiono na rycinie I).

$\mathrm{Z}$ kolei przeciętna tygodniowa liczba nowych zgłoszeń wynosiła 13,5 [min. 3 w 13. i 16. tygodniu funkcjonowania MLW (15-19 czerwca 2020 i 6-10 lipca 2020), maks. 36 w 2. tygodniu funkcjonowania MLW (30 marca-3 kwietnia 2020)]. Różnice w średniej częstości zgłoszeń w zależności od dnia tygodnia były niewielkie $(2,7$ w środy, 2,8 w czwartki i piątki, 3,0 w poniedziałki i wtorki). Blisko dwie trzecie interwencji (62\%) było realizowanych w godzinach 11.00-16.00.

\footnotetext{
${ }^{1}$ Uwzględniając tylko pełne miesiące, w czasie których funkcjonowała MLW (kwiecień-lipiec), średnia miesięczna liczba nowych zgłoszeń wynosiła 56.
} 
Table 1. Numbers and percentages of helpline callers by gender and type of intervention $(N=262)$

Tabela 1. Liczebności i odsetki osób korzystających z Mokotowskiej Linii Wsparcia, z uwzględnieniem płci i rodzaju interwencji $(N=262)$

\begin{tabular}{|l|c|c|c|c|c|c|}
\hline \multirow{2}{*}{ Gender/Płeć } & \multicolumn{2}{|c|}{$\begin{array}{c}\text { Total interventions/ } \\
\text { Wszystkie interwencje łącznie }\end{array}$} & \multicolumn{2}{|c|}{$\begin{array}{c}\text { Cyclical interventions/ } \\
\text { Interwencje cykliczne }\end{array}$} & \multicolumn{3}{c|}{$\begin{array}{c}\text { Ad hoc interventions/ } \\
\text { Interwencje doraźne }\end{array}$} \\
\cline { 2 - 7 } & $\boldsymbol{n}$ & $\%$ & $\boldsymbol{n}$ & $\%$ & $\boldsymbol{n}$ & $\%$ \\
\hline Male/Mężczyźni & 86 & 32.8 & 30 & 39.0 & 56 & 30.3 \\
\hline Female/Kobiety & 167 & 63.7 & 47 & 61.0 & 120 & 64.9 \\
\hline Missing data/Brak danych & 9 & 3.4 & 0 & 0 & 9 & 4.9 \\
\hline
\end{tabular}

Table 2. Numbers and percentages of helpline callers by age range and type of intervention $(N=262)$

Tabela 2. Liczebności i odsetki osób korzystających z Mokotowskiej Linii Wsparcia, z uwzględnieniem przedziałów wiekowych i rodzaju interwencji $(N=262)$

\begin{tabular}{|c|c|c|c|c|c|c|}
\hline \multirow{2}{*}{$\begin{array}{l}\text { Age range (years)/ } \\
\text { Przedział wiekowy (lata) }\end{array}$} & \multicolumn{2}{|c|}{$\begin{array}{c}\text { Tołal interventions/ } \\
\text { Wszystkie interwencje łącznie }\end{array}$} & \multicolumn{2}{|c|}{$\begin{array}{l}\text { Cyclical interventions/ } \\
\text { Interwencje cykliczne }\end{array}$} & \multicolumn{2}{|c|}{$\begin{array}{l}\text { Ad hoc interventions/ } \\
\text { Interwencje doraźne }\end{array}$} \\
\hline & $n$ & $\%$ & $n$ & $\%$ & $n$ & $\%$ \\
\hline$<30$ & 22 & 8.4 & 7 & 9.1 & 15 & 8.1 \\
\hline $30-49$ & 45 & 17.2 & 20 & 26.0 & 25 & 13.5 \\
\hline $50-69$ & 35 & 13.4 & 15 & 19.5 & 20 & 10.8 \\
\hline$>69$ & 13 & 5.0 & 8 & 10.4 & 5 & 2.7 \\
\hline Missing data/Brak danych & 147 & 56.1 & 27 & 35.1 & 120 & 64.9 \\
\hline
\end{tabular}

In the subgroup of people receiving cyclical support, the average number of interventions was 4.55 ( $\mathrm{min} .2$; max. 20). The average interval between calls was 4.8 days (min. 1; max. 28). Total support cycle time averaged 16.8 days (min. 2; max. 99).

Among the enrollees, there were approximately twice as many females $(n=167 ; 63.7 \%)$ as males $(n=86 ; 32.8 \%)$; for 9 individuals $(3.4 \%)$, the gender of the enrollee was not recorded on the intervention cards. The gender proportions of the subgroups receiving cyclical and ad hoc support were similar - see Table 1 for details.

The age distribution of the beneficiaries, including a division into cyclical and ad hoc support, is presented in Table 2. Notably, quite a lot of data is missing. However, whether these deficiencies were due to callers actually refusing to provide information (a refusal to give data did not affect support provision) was not recorded. Thus, it was impossible to determine whether the data is missing due to a caller's refusal or the inaccurate completion of cards by the MLW staff. Based on the limited data available, there is an emerging trend that people aged 30-49 were most likely to use the helpline, followed by people aged 50-69.

The most common reasons for contacting the helpline were seeking advice and support for symptoms of mental disorders presented by a loved one or a person under caller's care ( $n=56 ; 21.4 \%)$, seeking medical services such as an appointment with a psychiatrist, prescription renewal, and a psychotherapy appointment ( $n=42 ; 16.0 \%)$, and
Spośród całej grupy osób kontaktujących się z MLW $(N=262)$ wsparcie doraźne otrzymało 185 osób $(70,6 \%)$, a wsparcie cykliczne - 77 osób $(29,4 \%)$. W podgrupie osób korzystających ze wsparcia cyklicznego średnia liczba interwencji wynosiła 4,55 (min. 2, maks. 20). Przeciętny odstęp między poszczególnymi rozmowami wynosił 4,8 dnia (min. 1, maks. 28). Sumaryczny czas cyklu wsparcia trwał średnio 16,8 dnia (min. 2, maks. 99).

Wśród osób zgłaszających się około dwukrotnie więcej było kobiet $(n=167 ; 63,7 \%)$ niż mężczyzn $(n=86$; $32,8 \%$ ); w przypadku 9 osób $(3,4 \%)$ w kartach interwencji nie odnotowano płci osoby zgłaszającej się. Proporcje płci w podgrupach otrzymujących wsparcie cykliczne i doraźne były zbliżone - szczegóły przedstawiono w tabeli 1 .

Rozkład wieku osób korzystających z MLW, z uwzględnieniem podziału na wsparcie cykliczne i doraźne, został przedstawiony w tabeli 2 . Uwagę zwracają liczne braki w danych. Nie notowano jednak w sposób systematyczny, czy braki te wynikały z odmowy podania stosownych informacji przez osoby telefonujące (przyjęto zasadę, że taka odmowa nie wyklucza możliwości uzyskania wsparcia), nie jest więc możliwe ustalenie, w jakim stopniu były związane z tym czynnikiem, a w jakim z niedokładnym wypełnieniem kart interwencji przez osoby obsługujące MLW. Na podstawie dostępnych, ograniczonych danych można zaobserwować zarysowującą się tendencję, że najczęściej ze wsparcia korzystały osoby w wieku 30-49 lat, a w następnej kolejności osoby w wieku 50-69 lat.

Najczęstszymi powodami kontaktu z MLW były: chęć uzyskania porady i wsparcia w związku z objawami zaburzeń psychicznych występującymi u bliskiej osoby lub 
anxiety disorders ( $n=41 ; 15.6 \%)$. Slightly less common were reactive (adjustment) disorders $(n=34 ; 13.0 \%)$, depressive disorders $(n=15 ; 5.7 \%)$, financial difficulties or job loss $(n=15 ; 5.7 \%)$, as well as seeking information about the operation of the helpline or the Project $(n=13$; $5.0 \%)$. Among other reasons for contact were also domestic violence $(n=11 ; 4.2 \%)$, personality disorder decompensation and other dysfunctional behavior patterns $(n=8 ; 3.0 \%)$, and also psychotic disorders $(n=4 ; 1.5 \%)^{2}$. Other less frequent motives for calling (23 total; 8.8\%) were suicidal thoughts, difficulty adjusting to sanitary and epidemiological restrictions, contact-seeking, and being involved in conflicts.

In the subgroup receiving cyclical support $(n=77)$ the highest representation was among individuals with anxiety disorders $(n=21 ; 27.3 \%)$ and reactive disorders $(n=21 ; 27.3 \%)$, followed by those with depressive disorders $(n=9 ; 11.7 \%)$.

The subgroup of individuals who received ad hoc support $(n=185)$ mostly consisted of individuals reporting problems related to symptoms of distress in a loved one or a person under caller's care $(n=54$; $29.2 \%$ ), individuals in need of various types of medical services $(n=41 ; 22.2 \%)$, and those with anxiety disorders $(n=20 ; 10.8 \%)$.

Of the interventions carried out $(N=599)$, most consisted of psychological support $(n=442 ; 73.8 \%)$, information or psychoeducation in a broad sense $(n=101$; $16.9 \%)$, and referral to institutions capable of providing the best help ( $n=49 ; 8.1 \%)$. Emergency services were notified in one case, when the caller declared a wish to commit suicide.

\section{DISCUSSION}

The MLW was launched in response to public demand and proved to be useful in providing support to the general public in the face of an unprecedented epidemiological crisis. Although the total number of interventions $(N=599)$ was high, it was lower than expected (despite the extensive public information campaign).

\footnotetext{
${ }^{2}$ The categorization of psychiatric disorders as a reason for calling was based on an analysis of the total information contained in the intervention cards, including not only the currently predominant symptoms but also the course, severity, and disabling nature of the complaints. Assignment of the anxiety disorder and depressive disorder categories required finding information about treatment history or the presence of a severe symptom complex causing a marked impairment in functioning. The adjustment disorder category was assigned when there was a clear situational background, no history of treatment or past mental health problems, and when symptoms did not cause significant impairment of functioning. The psychotic disorder category, on the other hand, was assigned not only on the basis of the current presence of psychotic symptoms, such as delusions or hallucinations, but also when the caller disclosed that he or she had been diagnosed with a psychotic disorder.
}

podopiecznego ( $n=56 ; 21,4 \%)$, chęć uzyskania świadczeń medycznych, np. zapisu do psychiatry, otrzymania recept lub zapisu na psychoterapię ( $n=42 ; 16,0 \%)$ oraz zaburzenia lękowe $(n=41 ; 15,6 \%)$. Nieco mniej częste powody kontaktu to: zaburzenia reaktywne (adaptacyjne) $(n=34 ; 13,0 \%)$, zaburzenia depresyjne $(n=15 ; 5,7 \%)$, trudności finansowe lub utrata pracy $(n=15 ; 5,7 \%)$ oraz poszukiwanie informacji dotyczących działania infolinii lub Projektu ( $n=13 ; 5,0 \%)$. W dalszej kolejności notowano następujące powody kontaktu: przemoc domowa ( $n=11 ; 4,2 \%)$, dekompensacja zaburzeń osobowości i inne dysfunkcjonalne wzorce zachowań $(n=8 ; 3,0 \%)$ oraz zaburzenia psychotyczne $(n=4 ; 1,5 \%)^{2}$. Pozostałe, rzadsze motywy zgłoszeń (łącznie 23 osoby; 8,8\%), to: myśli samobójcze, trudności $\mathrm{w}$ dostosowaniu się do ograniczeń sanitarno-epidemiologicznych, poszukiwanie kontaktów i konflikty z otoczeniem.

W podgrupie otrzymującej wsparcie cykliczne $(n=77)$ najliczniej reprezentowane były osoby $\mathrm{z}$ zaburzeniami lękowymi $(n=21 ; 27,3 \%)$ i z zaburzeniami reaktywnymi $(n=21 ; 27,3 \%)$, a w dalszej kolejności z zaburzeniami depresyjnymi $(n=9 ; 11,7 \%)$.

$\mathrm{W}$ podgrupie osób, które otrzymały wsparcie doraźne $(n=185)$, przeważały osoby zgłaszające problemy związane z objawami zaburzeń u bliskiej osoby lub podopiecznego $(n=54 ; 29,2 \%)$, osoby wyrażające chęć uzyskania różnego rodzaju świadczeń medycznych $(n=41 ; 22,2 \%)$ oraz osoby z zaburzeniami lękowymi $(n=20 ; 10,8 \%)$.

Spośród przeprowadzonych interwencji $(N=599)$ najwięcej polegało na udzieleniu wsparcia psychologicznego ( $n=442 ; 73,8 \%)$, udzieleniu informacji lub przeprowadzeniu szeroko pojętej psychoedukacji $(n=101 ; 16,9 \%)$ oraz przekierowaniu do instytucji świadczących pomoc najbardziej adekwatną w danej sytuacji $(n=49 ; 8,1 \%)$. W jednym przypadku, ze względu na deklaracje samobójcze osoby dzwoniącej, powiadomiono odpowiednie służby.

\section{DYSKUSJA}

Mokotowska Linia Wsparcia została uruchomiona w odpowiedzi na oddolne zapotrzebowanie i okazała się użytecznym narzędziem wsparcia ludności w obliczu niemającego precedensu w ostatnich dekadach kryzysu epi-

${ }^{2}$ Kategoryzacji zaburzeń psychicznych jako powodu zgłoszenia dokonywano w oparciu o analizę całości informacji zawartych w kartach interwencji, obejmujących nie tylko dominujące obecnie objawy, ale również przebieg, nasilenie i upośledzający charakter dolegliwości. Przypisywanie kategorii zaburzeń lękowych i zaburzeń depresyjnych odbywało się na podstawie informacji o historii leczenia lub obecności zespołu objawów o nasileniu powodującym wyraźne pogorszenie funkcjonowania. Kategoria zaburzeń adaptacyjnych była nadawana w przypadku wyraźnego tła sytuacyjnego, braku historii leczenia czy problemów natury psychicznej w przeszłości, oraz w sytuacji, gdy objawy nie powodowały znaczącego upośledzenia funkcjonowania. Z kolei kategoria zaburzeń psychotycznych była przypisywana nie tylko na podstawie aktualnego występowania objawów psychotycznych, takich jak urojenia czy halucynacje, ale również w sytuacji, gdy zgłaszająca się osoba ujawniała fakt rozpoznania u niej zaburzeń psychotycznych. 
This may have been, at least partly, due to the digital exclusion of people with most severe mental disorders (and thus in greatest need of emergency support), and their difficulties in accessing information about the helpline, as well as the lack of public trust in this kind of support. There was also a gradual decline in interest in the help provided by the helpline over the months following the beginning of its operation. It is likely that a sense of confusion and uncertainty, as well as the fears and anxieties experienced by the public, were most strongly expressed during the first phase of the epidemic, when the threat was completely new and unknown. Another reason for the decreasing frequency of calls over time may have been the rapidly growing number of free psychological support initiatives (telephone, remote) offered by various other institutions, non-profit organizations, mental health centers and even privately owned facilities. Also, over the course of a few months telephone consultations by health care practitioners became widespread.

The helpline was contacted twice as often by women as men. How much of this was due to women being more vulnerable to the stress of a threat posed by the pandemic [4] and therefore in greater need of support, and how much was due to men being more reluctant to disclose their difficulties and seek help, is open for discussion and certainly worth exploring. It is known, for example, that men are less likely to admit directly that they feel lonely [16].

The results suggest that middle-aged people were most likely to use the helpline. While data on the callers' age is quite incomplete and should be treated with caution, when organizing future similar projects, it is important to make every effort to reach out to older people who may be particularly helpless under conditions of isolation and find it difficult to access traditional methods of psychological support.

The most common reason for contacting the helpline (just over one-fifth of all calls) was the need for advice in a situation in which the loved one, family member or a person under caller's care displayed symptoms of mental disorder or mental illness. This clearly indicates that despite many public information campaigns, social awareness of mental illness and the conduct required in the event of disturbing symptoms is still relatively low. It appears that people who are closest to those who experience the various manifestations of mental crises are most in need of reliable psychoeducation, and that helplines can be a useful source of it. In addition to the knowledge of procedures for dealing with specific mental disorders or illnesses, helpline operators should also have the knowledge of the mental health care system and the means of accessing mental health services. A comprehensive list of local and national mental health ser- demiologicznego. Choć łączna liczba interwencji $(N=599)$ była znacząca, to jednak niższa, niż się spodziewano (mimo szeroko zakrojonej akcji informacyjnej). Mogło to przynajmniej częściowo wynikać z wykluczenia cyfrowego osób doświadczonych najcięższymi zaburzeniami psychicznymi (a tym samym najbardziej potrzebujących pomocy w sytuacji zagrożenia) i związanych $\mathrm{z}$ tym trudności $\mathrm{w}$ dotarciu do informacji o MLW, a także z braku zaufania do tego rodzaju wsparcia. Obserwowano również stopniowy spadek zainteresowania wsparciem udzielanym przez MLW w ciągu kolejnych miesięcy jej funkcjonowania. Prawdopodobnie poczucie zagubienia i niepewności oraz lęki i obawy doświadczane przez społeczeństwo zostały najsilniej wyrażone w pierwszej fazie epidemii, gdy zagrożenie było jeszcze nowe i nieznane. Inną z przyczyn malejącej z czasem częstości zgłoszeń mogła być szybko rosnąca liczba inicjatyw bezpłatnej pomocy psychologicznej (telefonicznej, zdalnej) oferowanej przez różne instytucje, organizacje pożytku publicznego, centra zdrowia psychicznego, a nawet placówki prywatne. Kolejne miesiące pandemii przynosiły też upowszechnienie świadczeń zdrowotnych odbywających się zdalnie (teleporady) na szeroką skalę.

Z linią wsparcia dwukrotnie częściej kontaktowały się kobiety niż mężczyźni. Pozostaje kwestią otwartą, i z pewnością jest warte zbadania, na ile wynikało to $\mathrm{z}$ faktu, że kobiety są bardziej podatne na stres związany $\mathrm{z}$ takim zagrożeniem jak pandemia [4], i w związku z tym $\mathrm{w}$ większym stopniu potrzebują wsparcia, a na ile było to efektem większej niechęci mężczyzn do ujawniania swoich trudności i szukania pomocy. Skądinąd wiadomo na przykład, że mężczyźni są mniej skłonni przyznawać wprost, że czują się samotni [16].

Wyniki sugerują, że z linii wsparcia stosunkowo najchętniej korzystały osoby w średnim wieku. Zastrzegając, że dane dotyczące wieku osób zgłaszających się są niepełne i należy je traktować z ostrożnością, wydaje się ważne, aby przy organizacji kolejnych podobnych przedsięwzięć dołożyć wszelkich starań, żeby dotrzeć ze stosownymi informacjami o oferowanym wsparciu do osób w podeszłym wieku, które mogą być szczególnie bezradne w warunkach izolacji i utrudnionego dostępu do tradycyjnych metod pomocy psychologicznej.

Najczęstszym powodem kontaktu z MLW (nieco ponad jedna piąta zgłoszeń) była chęć uzyskania porady w sprawie najbliższej osoby, członka rodziny czy podopiecznego przejawiającego objawy zaburzeń psychicznych lub choroby psychicznej. Wskazuje to jasno na fakt, że mimo licznych kampanii informacyjnych świadomość społeczna dotycząca chorób psychicznych i zasad postępowania w przypadku pojawienia się niepokojących objawów ciągle jest stosunkowo niewielka. Najbliższe otoczenie osób doświadczających różnych przejawów kryzysów psychicznych potrzebuje rzetelnej psychoedukacji i wydaje się, że linia wsparcia może być jej przydatnym źródłem. Oprócz znajomości zasad postępowania w przypadku konkretnych zaburzeń czy chorób psychicznych osoby obsługujące linię wsparcia powinny zatem dysponować również wiedzą o funkcjonowaniu systemu psychiatrycznej opieki zdrowotnej i zasadach kontaktu 
Helpline provision during the first wave of the COVID-19 pandemic: experiences of the Mokotow Mental Health Center Linia wsparcia w czasie pierwszej fali pandemii COVID-19: doświadczenia Mokotowskiego Centrum Zdrowia Psychicznego

vices with contact information must be compiled prior to the launch of the helpline.

The second most common reason for calling the line (16\%) was the need for health services in the form of a doctor's appointment, prescription renewal, referral or psychotherapy. This is probably due to the fact that announcements about launching the helpline were made on the MCZP website and therefore may have been associated with medical support. In addition, some callers may have insufficiently understood the difference between the role of the helpline and the assistance provided under the umbrella of medical services. However, misunderstanding was not always the reason. Due to the difficulties in accessing outpatient services during the first weeks of the outbreak, some people called the helpline out of helplessness, asking for mediation in an attempt to gain access to healthcare services. Again, it may be helpful to create a list of contacts (including the medical units closest to the helpline area) and to train staff in the related procedures.

Next on the list of reasons for contacting the helpline were health problems, categorized most often as anxiety disorders (15.6\%), followed by reactive (adjustment) disorders (13\%) and depressive disorders $(5.7 \%)$. This does not come as a surprise, as an increase in these particular categories of mental health problems has been consistently reported since the outbreak of the COVID-19 pandemic [3, 4, 15]. For callers who reported such problems, cyclical support was proportionately more likely to follow. Sometimes it also required a referral to outpatient treatment, building a caller's motivation for treatment, and psychoeducation about mental disorders.

Loss of a job or financial difficulties unrelated to any obvious symptoms of mental disorders or illness were reported relatively rarely, by less than $6 \%$ of callers. It is likely that these kinds of problems are regarded as particularly embarrassing and therefore help is not readily sought. It should also be considered that the economic crisis affected people more later into the epidemic. The support provided to callers with this type of problem was rare and more often involved a social worker.

Despite the media coverage of the increase in domestic violence in conditions of forced isolation, this problem was rarely reported by callers (just over $4 \%$ ). This may be related to the hours of the helpline's operation, again 8 a.m. -8 p.m. People who experience domestic violence usually use a hotline in the absence of the perpetrator or at nighttime when the perpetrator is asleep. This may not have been an option in this situation. Additionally, people threatened by domestic violence may have tended to choose helplines specifically targeting their needs. (e.g., Blue Line, emergency helplines). z nim. Uruchomienie linii wsparcia warto poprzedzić przygotowaniem wykazu instytucji pomocowych w zakresie zdrowia psychicznego, zarówno lokalnych, jak i ogólnopolskich, wraz z danymi kontaktowymi, aby tego rodzaju informacje były szybko dostępne.

Drugim co do liczebności powodem zgłoszeń (16\%) była chęć uzyskania świadczenia zdrowotnego (wizyty lekarskiej, recepty, skierowania, psychoterapii). Po części wynikało to zapewne $\mathrm{z}$ faktu, iż ogłoszenia o działaniu MLW znajdowały się na stronach internetowych MCZP i mogły być kojarzone przez odbiorców ze wsparciem medycznym. Ponadto niektóre osoby kontaktujące się z MLW mogły niedostatecznie rozumieć różnicę między zasadami działania linii wsparcia a pomocą $\mathrm{w}$ ramach świadczeń udzielanych przez jednostkę medyczną. Nie zawsze jednak powodem musiało być nieporozumienie. Ze względu na utrudniony dostęp do usług ambulatoryjnych $\mathrm{w}$ pierwszych tygodniach stanu epidemii w Polsce część osób dzwoniła na numer MLW z bezsilności, prosząc o pośrednictwo w uzyskaniu świadczenia medycznego. Również w takim przypadku pomocne może okazać się stworzenie wykazu przydatnych kontaktów (w tym do jednostek medycznych najbliższych obszarowi działania linii wsparcia) oraz przeszkolenie personelu $\mathrm{z}$ zasad kontaktu $\mathrm{z}$ jednostkami medycznymi w sytuacjach tego wymagających.

$\mathrm{Na}$ kolejnych miejscach pod względem motywów kontaktu z MLW pojawiają się problemy zdrowotne, kwalifikowane najczęściej jako zaburzenia lękowe (15,6\%), a w dalszej kolejności jako zaburzenia reaktywne (adaptacyjne) (13\%) i zaburzenia depresyjne (5,7\%). Nie jest to zaskakujące, gdyż wzrost odsetków tych właśnie kategorii problemów psychicznych jest konsekwentnie wiązany z pandemią COVID-19 [3, 4, 15]. W przypadku osób $\mathrm{z}$ ww. problemami proporcjonalnie częściej konieczne okazywało się wsparcie cykliczne, które czasami wymagało jednoczesnego kierowania do lecznictwa ambulatoryjnego, budowania motywacji do podjęcia leczenia oraz psychoedukacji dotyczącej zaburzeń psychicznych.

Utrata pracy lub trudności finansowe, niepowodujące jednak ewidentnych objawów zaburzeń lub chorób psychicznych, były zgłaszane relatywnie rzadko - przez niespełna $6 \%$ osób. Możliwe, że problemy tego rodzaju uchodzą za szczególnie wstydliwe, dlatego nie są chętnie zgłaszane. Należy też wziąć pod uwagę, że kryzys ekonomiczny dopiero w kolejnych miesiącach epidemii stawał się coraz boleśniej odczuwalny. Wsparcie osób zgłaszających tego rodzaju problemy było na ogół epizodyczne i częściej niż w innych sytuacjach zaangażowany w nie był pracownik socjalny.

Mimo częstych doniesień medialnych o nasileniu zjawiska przemocy domowej w warunkach wymuszonej izolacji, problem ten nie był zgłaszany często przez osoby dzwoniące na numer MLW (nieco ponad 4\%). Może to wiązać się z godzinami funkcjonowania MLW (8.00-20.00), gdyż osoby doświadczające przemocy domowej korzystają z infolinii pomocowych pod nieobecność sprawcy w domu lub w godzinach nocnych (kiedy sprawca śpi). W tej sytuacji mogło nie być takiej możliwości. Dodatkowo osoby z tego rodzaju problemem mogły wybierać raczej pomoc infolinii 
Contrary to expectations, a call required to emergency services regarding a person in a suicidal state occurred only once. Interventions of this nature place the greatest strain on the helpline staff; even the expectation of them is highly stressful. In such situations, the role of support from other team members, cooperation and good communication with health care providers, as well as the knowledge of previously well-defined procedures, are of the highest importance.

It is worth noting that as many as $29 \%$ of callers received support in the form of cyclical help, which goes beyond the typical scope of hotline assistance, generally designed for ad hoc interventions, and further help is only provided when a person calls the hotline again and most often they cannot receive support from the same staff. Two-thirds of people in this group are classified as having anxiety disorders, reactive disorders, or depressive disorders. In fact, it seems that there is a great need for this kind of support, especially among people with relatively well-established mental health problems, which occasionally reach clinical severity.

\section{LIMITATIONS}

The main limitations of the study stem from the fact that the information analyzed was collected for practical purposes related to the requirements of documenting the interventions implemented through the helpline. The research purposes were secondary, so the nature of the data allowed for only simple analysis. The categories of mental disorders determined on the basis of their description and interview summarized in the intervention cards should also be treated with caution. Thus, our conclusions should be treated as preliminary, although in the authors' opinion - of solid practical value.

\section{CONCLUSIONS}

In conclusion, a helpline can be a readily available and practical means of providing assistance to the general public in a critical situation, such as a pandemic. The type, duration, and intensity of assistance should be varied and tailored to the wide range of problems reported by callers. A helpline can serve as a source of information, provision of ad hoc interventions, and, when warranted, cyclical interventions. Finally, it can play an important role as a screening tool for mental disorders that require medical attention, and in this way facilitate contact with mental health services. skierowanych właśnie do osób doświadczających przemocy (np. Niebieska Linia, telefon zaufania).

Wbrew oczekiwaniom, interwencja wymagająca wezwania służb ratunkowych w sytuacji kryzysu samobójczego miała miejsce tylko raz. Interwencje tego rodzaju stanowią największe obciążenie dla osób obsługujących linię wsparcia. Nawet sama świadomość, że mogą się wydarzyć, może być źródłem silnego stresu. W takich sytuacjach nie sposób przecenić roli wsparcia ze strony innych pracowników zespołu oraz współpracy i dobrej komunikacji $\mathrm{z}$ instytucjami ochrony zdrowia zgodnie z wcześniej wypracowanymi procedurami postępowania.

Warto zauważyć, że aż $29 \%$ osób kontaktujących się $\mathrm{z}$ MLW otrzymywało wsparcie $\mathrm{w}$ formie cyklicznej. Jest to pomoc wykraczająca poza typowe zadania infolinii pomocowych, których założeniem jest na ogół prowadzenie interwencji doraźnych, a kolejny kontakt jest możliwy, gdy dana osoba sama zgłosi się telefonicznie - najczęściej nie ma pewności, że uzyska wsparcie od tej samej osoby. Dwie trzecie osób z tej grupy to osoby zakwalifikowane jako przejawiające zaburzenia lękowe, zaburzenia reaktywne lub zaburzenia depresyjne. Wydaje się więc, że istnieje duże zapotrzebowanie na tego rodzaju wsparcie, zwłaszcza wśród osób z względnie utrwalonymi, niekiedy osiągającymi kliniczne nasilenie problemami psychicznymi.

\section{OGRANICZENIA}

Główne ograniczenia badania wynikają z faktu, że poddane analizie informacje były gromadzone dla celów praktycznych, związanych z wymogami dokumentowania realizowanych interwencji. Cel naukowy był wtórny. Dlatego też charakter danych pozwolił jedynie na prosty opis, niemożliwe zaś było zastosowanie zaawansowanych metod statystycznych. Z ostrożnością należy również podchodzić do kategorii zaburzeń psychicznych ustalanych na podstawie ich opisu i wywiadu zamieszczonego $\mathrm{w}$ kartach interwencji. Tym samym wnioski $\mathrm{z}$ badania powinno się traktować jako wstępne, choć - w ocenie autorów - niepozbawione walorów praktycznych.

\section{WNIOSKI}

Podsumowując, należy stwierdzić, że linia wsparcia może być łatwo dostępnym i praktycznym środkiem udzielania pomocy ludności w kryzysowej sytuacji, takiej jak pandemia. Rodzaj, czas trwania i intensywność tej pomocy powinny być zróżnicowane i dostosowane do szerokiego wachlarza problemów zgłaszanych przez osoby dzwoniące. Linia wsparcia może służyć jako źródło informacji, umożliwiać interwencje doraźne, a w uzasadnionych przypadkach również cykliczne. Może wreszcie odgrywać istotną rolę jako narzędzie screeningu w kierunku zaburzeń psychicznych wymagających pomocy medycznej i ułatwiać kontakt z placówkami świadczącymi tego rodzaju pomoc. 


\section{Conflict of interest/Konflikt interesu}

Absent./Nie występuje.

\section{Financial support/Finansowanie}

Absent./Nie występuje.

\section{Acknowledgements/Podziękowania}

The authors wish to thank the MLW facilitators and workers who completed 'intervention cards' who provided data for the present study, as well as the people who organized and managed the Project, without whom the study would not have been possible./Autorzy dziękują osobom obsługującym MLW i wypełniającym karty interwencji, które dostarczyły danych do obecnego badania, oraz osobom zaangażowanym w proces organizowania Projektu i zarządzania nim, bez których przeprowadzenie badania nie byłoby możliwe.

\section{References/Piśmiennicłwo}

1. Li H, Burm SW, Hong SH, Ghayda RA, Kronbichler A, Smith L, et al. A comprehensive review of coronavirus disease 2019: epidemiology, transmission, risk factors, and international responses. Yonsei Med J 2021; 62: 1-11.

2. Flaxman S, Mishra S, Gandy A, Unwin HJT, Mellan TA, Coupland H, et al. Estimating the effects of non-pharmaceutical interventions on COVID-19 in Europe. Nature 2020; 584: 257-261.

3. Rajkumar RP. COVID-19 and mental health: a review of the existing literature. Asian J Psychiatr 2020; 52: 102066.

4. Xiong J, Lipsitz O, Nasri F, Lui LMW, Gill H, Phan L, et al. Impact of COVID-19 pandemic on mental health in the general population: a systematic review. J Affect Disord 2020; 277: 55-64.

5. Bruffaerts R, Voorspoels W, Jansen L, Kessler RC, Mortier P, Vilagut G, et al. Suicidality among healthcare professionals during the first COVID19 wave. J Affect Disord 2021; 283: 66-70.

6. Groarke JM, Berry E, Graham-Wisener L, McKenna-Plumley PE, McGlinchey E, Armour C. Loneliness in the UK during the COVID-19 pandemic: cross-sectional results from the COVID-19 Psychological Wellbeing Study. PLoS One 2020; 15: e0239698.

7. Rosenberg M, Luetke M, Hensel D, Kianersi S, Fu TC, Herbenick D. Depression and loneliness during April 2020 COVID-19 restrictions in the United States, and their associations with frequency of social and sexual connections. Soc Psychiatry Psychiatr Epidemiol 2021. DOI: 10.1007/s00127-020-02002-8 [Epub ahead of print].

8. Holt-Lunstad J. A pandemic of social isolation? World Psychiatry 2021; 20: 55-56.

9. Szajnoga D, Klimek-Tulwin M, Piekut A. COVID-19 lockdown leads to changes in alcohol consumption patterns. Results from the Polish national survey. J Addict Dis 2021; 39: 215-225.

10. Jacob L, Smith L, Armstrong NC, Yakkundi A, Barnett Y, Butler L, et al. Alcohol use and mental health during COVID-19 lockdown: a cross-sectional study in a sample of UK adults. Drug Alcohol Depend 2021; 219 : 108488.

11. Brooks SK, Webster RK, Smith LE, Woodland L, Wessely S, Greenberg N, et al. The psychological impact of quarantine and how to reduce it: rapid review of the evidence. Lancet 2020; 395: 912-920.

12. Gambin M, Sękowski M, Woźniak-Prus M, Wnuk A, Oleksy T, Cudo A, et al. Generalized anxiety and depressive symptoms in various age groups during the COVID-19 lockdown in Poland. Specific predictors and differences in symptoms severity. Compr Psychiatry 2021; 105: 152222.

13. Holmes EA, O'Connor RC, Perry VH, Tracey I, Wessely S, Arseneault L, et al. Multidisciplinary research priorities for the COVID-19 pandemic: a call for action for mental health science. Lancet Psychiatry 2020; 7: 547-560.

14. Muller AE, Hafstad EV, Himmels JPW, Smedslund G, Flottorp S, Stensland SØ. The mental health impact of the covid-19 pandemic on healthcare workers, and interventions to help tchem: a rapid systematic review. Psychiatry Res 2020; 293: 113441.

15. Peppou LE, Economou M, Skali T, Papageorgiou C. From economic crisis to the COVID-19 pandemic crisis: evidence from a mental health helpline in Greece. Eur Arch Psychiatry Clin Neurosci 2021; 271: 407-409.

16. De Jong Gierveld J, van Tilburg T, Dykstra PA. Loneliness and social isolation. In: The Cambridge handbook of personal relationships. Vangelisti AL, Perlman D (eds.). Cambridge: Cambridge University Press; 2006, p. 485-500. 